\title{
Even sociologists need science
}

Sir-Science is not a cultural construct, not in the strong sense intended by Andrew Pickering. When his book Constructing Quarks first came out, I did not take its 'deconstruction' of high-energy physics very seriously. However, it is now the object of correspondence in your pages, Pickering is apparently unrepentant, and I feel personally implicated as one of the "opportunists in context" who supposedly infected the high-energy physics community with the quark-gauge theory disease, so I feel impelled to enter the fray.

Like your commentators Kurt Gottfried and Kenneth Wilson (Nature 386, 545-547; 1997), I do not have big complaints about chapters 2 to 13 of Constructing Quarks, although I would be more laudatory of the courage of the pioneering Gargamelle neutral-current discovery. These chapters are in general well researched, and I can vouch for details in which I was involved personally, such as the discovery of the gluon. My complaints are rather with the first and last chapters and the arguments Pickering advances in support of his thesis that "there is no obligation upon anyone framing a view of the world to take account of what twentieth-century science has to say". Since I was interviewed at length by Pickering for his book, I can only wonder whether he delights in being perverse. If he had written a hundred years ago, perhaps his book would have been called Constructing Atoms.
This is not the place to contest in detail the conclusions of his book, so I limit myself to taking issue with some of Pickering's remarks in his recent letter in your columns (Nature 387, 543; 1997). It is simply not true that "the old physics had the merit of explaining almost all of the phenomena that appear in the HEP [highenergy physics] laboratory".

The old physics was a collection of ad hoc recipes to fit limited aspects of the data produced before 1970: it does not explain phenomena seen at the Large Electron-Positron Collider, whereas the new physics explains them almost embarrassingly well.

Pickering vaunts the extensive bibliography of his book; unfortunately, it is out of date and potentially misleading. For example, his footnote 44 refers to five Z-boson events whose "statistical significance... was not overwhelming recall... the disappearing $6 \mathrm{GeV}$ upsilon". His potentially deconstructionist readers should perhaps be informed that by now almost 20 million $\mathrm{Z}$ particles have been observed, and that their properties agree to great accuracy with the electroweak sector of the Standard Model, which is even better tested than the successful quantum chromodynamics sector advertised by Gottfried and Wilson. By now, the Standard Model has predicted correctly the existence, masses and other properties of the charm quark, the $\mathrm{W}$ and $\mathrm{Z}$ bosons, and most recently the top quark: "we got it right" after all.

Pickering is fascinated by the "confusion of war" surrounding the emergence of a revolutionary new paradigm. Indeed, things are not obvious at the start, and one needs intuition and courage to abandon false trails, which provides much of the excitement in doing science. However, nature itself is the only arbiter, and Pickering seems to confuse subjective influences in this initial phase of a scientific revolution with the objective reality of the end result. He suffers from the familiar lack of interest of those studying the sociology of scientific knowledge in the subsequent confirmation of successful new paradigms, and I should also like him to document and compare more thoroughly the rejection by the scientific community of false "discoveries".

Until he presents a more rounded picture including these elements, the reader is entitled to reject Pickering's suggestion that "there is no obligation upon anyone framing a view of the world to take account of what twentieth-century science has to say". My guess is that he himself does take account of it: or perhaps he does not know or care how the Sun shines, does not believe in CD players, and flies in airliners that are navigated by sight?

Jonathan R. Ellis

CERN, 1211 Geneva 23,

Switzerland

\section{More danger in doctrine}

\section{than in genetics}

Sir - In response to recent press coverage of advances in genetics, you are quick to point out the imagined political and social dangers of a belief in biological determinism, citing Nazi Germany as a precedent (Nature 387, 743; 1997).

Perhaps you could explain to your readers why similar comments, quoting the vastly greater number of people who perished at the hands of regimes committed to the dogma of cultural determinism in the Soviet Union, China, Cambodia and elsewhere, are never made. Why is it that the death of millions of Jews is routinely hung around the neck of genetics, while that of millions more belonging to many different ethnic and social groups is never laid at the door of the sociological theories that were used to justify their persecution particularly when such theories are still widely taught and credited?

Surely, if doctrines were to have health warnings attached to them objectively assessed by the number of individuals they had harmed, the fashionable Marxist belief that the social environment is much more important than anything else would be rated many times more harmful than any acknowledgement of the influence of genes.

As you say, knowledge is power, but the power to kill millions during our century has come much more from the belief that human beings are the hapless victims of 'ideology', 'society' or 'class' than it has from any knowledge of genetics, however faulty or misapplied it may have been. Your leading article eloquently reveals the extent to which everyone is now acutely aware of the dangers of misapplied genetic knowledge. The real worry is that there is much less awareness of the potentially greater dangers of credulity for doctrines of social-determinism.

\section{Christopher Badcock}

London School of Economics,

Houghton Street, Aldwych,

London WC2A 2AE, UK

e-mail:badcock@lse.ac.uk
George Wald believed in

\section{Apocalypse now}

Sir — John Dowling ${ }^{1}$ pays a well-deserved tribute to George Wald's great contributions to the chemistry of vision.

Wald was also concerned with the disappearance of human beings. He said, in 1975, that he found it difficult "to see how the human race will get itself much past the year 2000".

Warming to his subject, he could find no reason to believe that his children and his students would "be in physical existence ten, twenty, twenty-five years from now"2. In short, “... life on Earth may end as early as $1985^{\prime 2,3}$. I am not aware that he retracted this statement.

Thomas H. Jukes

Department of Integrative Biology,

University of California, Berkeley,

Berkeley, California 94720-3140, USA

1. Dowling, J. Nature 387, 356 (1997).

2. Wald, G. Progressive, December 1975, pp 22-24.

3. Efron, E. The Apocalyptics (Simon and Schuster, New York, 1984). 